\title{
The Case Method in Library Education
}

W HILE TRADITIONAL methods of instruction have been through lectures, suggested reading, discussion, and examination, these methods have never proved to be satisfactory in the area of library administration. ${ }^{1}$ With the emergence of graduate programs in library science some seven to eight years ago, it became apparent that the lecture-discussion-reading approach was not acceptable. In large part, this stemmed from the fact that courses in library administration are, in a sense, not courses in librarianship. They are related rather to general considerations of administration as they might occur in any professional or business area.

In searching for a teaching technique that would meet the requirements of graduate courses in library administration, certain considerations were obvious. First, administration is an art rather than a science. It is less important to impart a body of knowledge to the student, and yet quite important to develop in the student a logical manner of thinking in terms of administrative problems and situations wherein he will make recall to all the resources, including his own training, experience, and the literature of the profession, which might apply to any given administrative problem. Administration, furthermore, is an art wherein solutions are relative to the

1 This article was adapted from material included in a "Preliminary Report to the Association of College and Reference Libraries and the United States Stee Foundation on a Grant to Aid in Research and Preparation of Case Studies Dealing With Current Administrative Problems in American Liberal Arts College Libraries," May 1, 1958.

$\mathrm{Mr}$. Shaffer is Director, School of Library Science, and Director, College Libraries, Simmons College, Boston. individual situation and the individuals in it. There are no "pat" answers. If courses in administration are to succeed at all, they must produce a student who is happy in the realization that any given problem may be satisfactorily handled by the library administrator in a variety of sometimes even opposed solutions. It requires the discovery of a technique that will mature the student rather than simply transfer a body of knowledge to him.

As we approached this teaching problem at Simmons some seven years ago, we began experimentally to try to evaluate teaching techniques in other professional areas involving similar objectives. The group dynamics approach, fashionable at that time, was found not to provide the solution. The use of audio-visual material similarly was unsatisfactoryespecially in terms of cost. The case method, upon trial, was found to promise the best results to the teacher of library administration.

The case method is one which perhaps has had its longest use in legal education, but as a teaching device it has reached its perfection in business education, and particularly at the Harvard Graduate School of Business. At Harvard, experiments in using case material in business education began as early as 1910, but within the last decade and a half the school has reached a refinement in this technique where now the entire sixteen courses comprising the two-year master's program in business administration are conducted solely by case presentations.

Accordingly, we began to experiment at Simmons in 1951 with this approach, and found that it promised a satisfactory 
technique for teaching library administration. We began cautiously-simply adding a few cases to administration courses toward the end of the term. Within a four- to five-year period the use of cases in administration courses had certainly proved itself, but an adequate trial was not possible because of the lack of a supply of good case material. As will be shown later, the grant received in February 1956, from the United States Steel Foundation, through the ACRL, made an adequate supply of such materials available to the point where we feel that the teaching problem has been more than satisfactorily resolved.

Although the use of cases at Simmons follows the methods used at Harvard very closely, various interpretations needed to be made in terms of library education. Briefly, the technique developed at Simmons is as follows. During the course of each administration class, some fifty cases are brought to the attention of the student. Most of these are relatively brief-from three to twelve single-spaced mimeographed pages. Some are advanced cases and vary from thirty to fifty pages in length. The two types of cases serve differing purposes and are handled quite differently in terms of class use.

Short cases are handed to the students in groups of from five to ten, and a clear indication is made to the student as to when the cases will be discussed in class. In preparing the cases for class use, the student reads each case through as many times as he or she requires, and then marshals all the information needed for the solution of the problem. This material may involve personal experience in libraries or other types of work situations. It certainly will involve all of the library science training that the student has received, and it may involve research into relevant professional literature and beyond such literature. It habituates the student to determine infor- mation needed to solve the case and then, either by synthesizing his own experience or by research, to acquire the necessary bases of solution. When this point has been reached, the student's next step is to try to think logically through the case and to reach logical administrative conclusions and evaluations. The student may be aided in this process by informal discussion with other members of the class. The final step in class preparation involves the student's preparing a speaking aide memoire which will help him in class participation, and which also serves important pedagogical functions for the instructor.

In the classroom, responsibility for case analysis is both voluntary and involuntary. The instructor first summarizes the case so that it is clearly differentiated from other cases which students have been preparing. He then reads a series of questions intended to be suggestive of the principles involved which appear at the end of each case. At this point the instructor calls upon a student to present the case. A solution to a case may take from five to fifteen minutes. The instructor then calls upon a second student to deal with the case. The second student may agree basically with the first presentation and simply add certain reservations, differing points of view, or additional comment. Or, the second person called upon may take an entirely opposed position in the solution of the case and make a complete analysis and solution in his own right. At this point the case is thrown open for voluntary class discussion, and usually at this stage there are as many people ready to participate in the discussion as there are students in the class. In the event that the two original speakers presented differing points of view, the class will usually line up in two camps, arguing the logic of their differing positions. When the case has been fully presented by students, its classroom presentation has 
been concluded. This conclusion frequently is in terms of two or at least three quite different points of view, for indeed there are no right or wrong answers to an administrative problem, and a feeling of security in the face of a situation which is essentially a subjective one is an important contribution of the case method. At the conclusion of the class the instructor asks for the aides memoire which all students have prepared, and thus has a clue to the thinking and progress of each member of the class for every case, even though some members of the class may not have spoken extensively in discussion. The aides memoire in the course of the term enable the instructor to follow the thinking processes of every student with accuracy and convenience.

Longer cases running from thirty to fifty or even more pages, rather than dealing with a specific administrative situation or "incident," deal with a total institution, or with some large segment of an institution. In longer cases, the solution is prepared by the student in a carefully written report which may itself run to twenty or twenty-five pages. The function of these written analyses is to give the instructor a direct clue not only to the thinking process of the student but also to the methods he has used, the depth at which he has integrated his own experience, his professional training, his research in solving the case and, finally, his ability to handle a larger and more complex situation in concise, logical written form.

The foregoing will indicate that the position of the instructor, where the case method is used, is an unusually exciting one. It has sometimes been said that with the interest which the case method invariably stimulates, the role of the instructor becomes that of a kind of traffic "cop" whose business is first to keep discussion moving along profitable channels and away from irrelevant tangents and, on the other hand, to keep students from giving each other black eyes! Many a veteran teacher will testify that this is quite a different role from the desultory and polite discussion that all to frequently results from the lecture method. To be sure, the demands made upon the instructor seem far greater than in the traditional forms of teaching, but this is compensated for by the enthusiasm and excitement of the classroom experience, and by the growth of the student in terms of his reasoning abilities as such a course progresses.

With the resources which the United States Steel Foundation and ACRL grant made available, the School of Library Science was prepared for the first time to gather systematically case materials. This in itself was a new experience both here and in the library field, for heretofore case materials were drawn from personal experience or experience at second hand that suggested itself with case applicability. In approaching this activity on a larger basis than in the past, we soon discovered that we had much to learn, and that there were many factors that required attention that had not been anticipated.

By way of illustration, we knew that the Graduate School of Business Administration of Harvard University had little or no difficulty in collecting case materials. The Harvary School of Business Administration is well known and, furthermore, it has a distinguished body of alumni who have infiltrated many of the larger businesses which it might wish to use as a source of case materials. Certainly its three decades of interest in case studies are well known in the business area. For this reason, an invitation on the part of the Graduate School of Business Administration to a firm to participate in a case study almost invariably is received with welcome. The researchers who are sent to gather case information are given every facility and help, and the firm "surveyed" usually feels a sense of satisfaction, if not flat- 
tery, for being involved in the educational process in this way.

We soon learned that at this juncture, at least, a similar psychology does not always prevail among librarians. We discovered in the course of expeditions to various libraries that even an oblique reference to the collecting of case materials often produced a defensive reaction. Even if it did not outrightly result in a lack of welcome, it served as a deterrent in many instances to the gathering of case information. Similarly, even when it was possible to persuade a library to become the subject of a case, permission to use the case for classroom purposes and to reproduce the case in mimeographed form as a teaching vehicle was frequently impossible, or, at least, difficult and time-consuming to obtain. Where permission was granted, it frequently required a period of six months for the submitted case to go through the channels of the parent authorities. This reluctance sometimes occurred even though it was suggested that the library's actual identity be disguised so that it could not be readily recognized except by those who were intimately familiar with it.

A completed case is not a dependable teaching tool until it has been tested in the classroom at least once and preferably twice. Classroom use frequently indicates the omission of important information that proves relevant to a consideration of the case-or, in a very rare number of instances, it may indicate that the case must be entirely rewritten or even discarded. This means of course that before cases could be considered completed, considerable time might be required to gather and write the case itself, to secure permission to use the case, and then to fit it into the classroom situation effectively.

The length of time required in the process of producing a tested, extended case study of a complete in- stitution is particularly protracted. In the gathering of case materials it was found that a special talent and training is required on the part of the case researcher and writer. Many people who have administrative potential or experience and who would seem to have every prerequisite for the task simply failed to have a sense of the case situation, so that the choice of individuals to assist in the execution of the grant became a very important factor in the process.

The reluctance of librarians and their parent administrative authorities to participate in the project is partly accounted for by the newness of the case method in the library field, and undoubtedly it will tend to disappear as the case method becomes more common in library education. This reluctance has even more serious implications. It has become a serious factor in the use and certainly in the publication, in the larger sense of that word, of case materials. In spite of the most careful attention to the disguising of certain cases, in more than one instance an attempt has been made to identify a case with a particular institution. While I should not want to indicate by any means that publication of the cases, or most of the cases that have been gathered, is impossible, I should like to report that legal investigation will need to be made before publication in any general form, such as a book, can be contemplated. Legal investigation on this point is now being made, and every attention to this factor is being taken cognizance of in case writing and editing.

While the application of the case method to library education should never cover all or even a large part of the library science curriculum, at Simmons it has enabled us to develop a teaching technique that may have significant effects upon library education. As indicated, such effects are already apparent at Simmons. 